\title{
INTERNALISASI NILAI-NILAI KARAKTER DAN KEPRIBADIAN MAHASISWA PENDIDIKAN AGAMA ISLAM MELALUI PENDEKATAN HUMANIS-RELIGIUS
}

\author{
Puspo Nugroho \\ STAIN Kudus, Jawa Tengah, Indonesia \\ pusponugroho@stainkudus.ac.id
}

\begin{abstract}
CHARACTER VALUES AND PERSONALITY INTERNALISATION OFISLAMIC EDUCATION STUDENTS THROUGH HUMANISTRELIGIOUS APPROACH. Islamic Teacher Training and Education Faculty has a strategic role in the effort to counteract demoralization and dehumanization. One of the efforts is by maximizing the academic process. The purpose of this study is to discover how the implementation of character education through a religious humanist approach is. Sources of data were from leaders, lecturers of Personality Development Subject, student and related matters. To get the data more deeply, researcher used Snowball Technique. Techniques used for collecting data were multiple methods. They were interview, documentation and observation. The results show that the character education design is hiddencurriculum. In the process done through the activities of Tridarma Perguruan Tinggi. It can be implemented through emphasizing regulations of lectures and socialization. They are building harmonious, humanist and religious relationships, kinship, promoting compassion, positive habituation, building a positive mindset of students, meaningful learning, lecturers as the living model, and integration of Islamic values. The easy access to the source of religious values will be able to maximize the effort to have cadres of future teachers who have humanist and religious character and personality.
\end{abstract}

Keywords: Internalisation, Character, Humanist-Religious, Student 


\begin{abstract}
Abstrak
Fakultas Tarbiyah dan Keguruan Islam memiliki peran strategis dalam upaya menangkal demoralisasi dan dehumanisasi. Salah satu upayanya adalahdengan memaksimalkan proses akademik. Tujuan penelitian ini untuk mengetahuibagaimana pelaksanaan pendidikan karakter melalui pendekatan humanis religius. Sumber data berasal dari pimpinan dandosenMata kuliahPengembangan Kepribadian (MPK), mahasiswa dan hal-hal terkait. Untuk menjaring data lebih dalam, peneliti menggunakan teknik bola salju (Snowball Technique).Teknik pengumpulan data mengunakan multi metode yaituwawancara,dokumentasidan observasi. Hasil penelitian menunjukkan desain pendidikan karakter bersifat hiddenkurikulum. Pada prosesnya terlaksana melalui kegiatan Tridarma Perguruan Tinggi.Strategi pelaksanaanya yaitu melalui penekanan tata tertib perkuliahan dan sosialisasi. Membangun hubungan harmonis, humanis dan religius, kekeluargaan, mengedepankan rasa kasih sayang, pembiasaan positif, membangunmindsetpositifmahasiswa,p embelajaran bermakna, dosen sebagai the living model, dan integrasi nilai-nilai ajaran Islam. Dengan mudahnya akses terhadap sumber nilai agama akan mampu memaksimalkan upaya mencetak kaderkader guru masa depan yang memiliki karakter dan kepribadian humanis dan religius.
\end{abstract}

Kata Kunci: Internalisasi, Karakter, Humanis-Religius, Mahasiswa

\title{
A. Pendahuluan
}

Demoralisasi dan dehumanisasi di berbagai bidang kehidupan terlihat setiap saat, baik media cetak maupun media elektronik. Seiring perjalananpublik disuguhi dengan beritaberita penyimpangan akhlak, baik dalam bidang politik, hukum, ekonomi, pemerintahan dan bahkan dalam dunia pendidikan. Khususnya di dunia pendidikan diantaranya adalah kasus kecurangan yang terjadi dalam proses ujian, banyaknya tawuran antar sekolah dan generasi muda, maraknya pemakaian narkoba, free seks pada generasi muda bahkan juga terjadi dikalangan pegawai negeri, publik figure dan bahkan di kalangan pendidik, serta fenomena radikalisme di kalangan generasi muda, terutama di sekolah dan di perguruan tinggi seperti kasus NII (Latief $\mathrm{dkk}, 2015: 56)$. Sebagai contoh, fenomena radikalismelainnya dalam bidang pendidikan adalah tragedi yang terjadi ketika Masa 
Orientasi Siswa (MOS) yang dialami oleh salah satu mahasiswa ITN Malang yang meninggal akibat kekerasan yang diterima dari seniornya. Kasus lain adalah tewasnya Dimas salah satu mahasiswa STIP akibat luka memar yang diterima dari seniornya.Selain itu, yang baru saja terjadi dari kasus pencurian sampai pembunuhan antarsiswa di SMA Nusantara Magelang menambah deretan kasus dehumanisasi di lingkungan pendidikan.

Munculnya berbagai fenomena dehumanisasi dan demoralisasi diatas menjadikan sebuah tandadimana tatanan sosial masyarakat baik secara langsung maupun tidak langsung mulai dikesampingkan bahkan diabaikan yang pada akhirnya individu tidak jarang melanggar nilai nilai dasar kemanusiaan itu sendiri. Hal tersebut telah memicu terjadinya krisis nilai dan moral generasi bangsa.

Ditegaskan oleh Din Syamsudin dalam yang pada kala itu juga menjabat sebagai Wakil Ketua MUI Pusat (Majelis Ulama' Indonesia) menegaskan bahwa masalah yang dihadapi bangsa Indonesia ini berpangkal pada krisis moral. Hal ini terjadi karena bangsa Indonesia terjebak dalam permisivisme budaya dengan membiarkan dan mengabaikan proses dekadensi moral yang terjadi secara sistematis tanpa penggerak untuk mengatasi dan menghalanginya.

Menurut Zubaidi (2011:2),krisis yang melanda pelajarmahasiswa (juga elit politik) yang terjadi mengindikasikan bahwa begitu banyak manusia Indonesia yang tidak koheren antara ucapan dan tindakannya sehingga terjadi split personality. Kondisi tersebut, diduga berawal dari apa yang dihasilkan oleh dunia pendidikan.

Melihat kenyataan yang terjadi, Muslich (2011:17) menegaskan bahwaDunia pendidikan telah melupakan tujuan utama pendidikan, yaitu mengembangkan pengetahuan, sikap, dan keterampilansecara simultan dan seimbang. Dunia pendidikan kita telahmemberikan porsi yang sangat besar untuk pengetahuan, tetapimelupakan pengembangan sikap/nilai dan perilaku dalam pembelajarannya. Dunia pendidikan saat ini dalam prosesnya terkesan lebih mementingkan aspek kognitif semata. 
Meskipun demikian, profesi guru sebagai ujung tombak masih diakui memiliki banyak kontribusi terhadap pembentukan sikap, perilaku, serta ketercapaian transfer of learning kepada para peserta didik baik secara individu maupun kelompok. Guru menjadi salah satunya harapan penting bagi masyarakat tanpa mengenal batas-batas sosial.Tidak terbayangkan akan seperti apa masa depan generasi muda bangsa ini jika tanpa sentuhan guru yang profesional dan berkepribadian kuat. Salah satu alternatif menanamkan nilai-nilai luhur bangsa Indonesia yaitu dengan pendidikan. Dengan kata lain, Pendidikan adalah suatu sarana sosial, sarana dimana suatu masyarakat menjamin kelangsungan hidupnya. Guru adalah agen masyarakat, mata rantai yang sangat penting dalam pengalihan budaya. Tugas guru adalah menciptakan suatu makhluk sosial, suatu makhluk yang bermoral. Melalui guru, masyarakat menciptakan manusia sesuai dengan masyarakat itu sendiri(Durkheim,1961:xii)

Dalam sumber yang sama Durkheim (1961:xiii) menjelaskan bahwa Pendidikan adalah menciptakan makhluk baru. Tugas dan kemuliaan pendidikan bukan sekedar masalah tentang bagaimana seorang individu berkembang sesuai dengan kodratnya, atau mencoba menggali dan menemukan kemampuan yang masih terpendam dalam setiap individu.

Selama ini, pola pendidikan yang dilakukan antara guru sebagai penyampai ilmu pengetahuan dan guru sebagai fasilitator dan teladan bagi pengembangan kepribadian siswa masih belum imbang. Hal tersebut dipertegas oleh Rahardjo (2010:4)bahwa pola dan sistem pendidikan yang dihasilkan LPTK saat ini masih lebih menekankan sisi akademik daripada pengembangan kepribadian dan keterkaitan dengan dunia kerja.

Untuk itu, dari LPTK sendiri perlu melakukan langkahlangkah inovasi mulai dari kurikulum, sistem pendidikan, materi, dan pola pengajarannya sehingga menghasilkan guru yang bukan saja penyampai pengetahuan, tetapi juga sebagai pribadi profesional sebagaimana amanat Undang-undang Guru dan Dosen. Dengan kata lain, revitalisasi peran LPTK terhadap pendidikan karakter sudah sangat mendesak untuk dilakukan. 
Pendapat Durkheim diatas bersinergi dengan realita proses pendidikan di LPTK yang mencetak calon tenaga pendidik masa depan sebagai makhluk yang baru. Anies Baswedan dalam pengantar bukunya Munif Chatib (2012:xv)yang berjudul "Gurunya Manusia" menjelaskan bahwa yang terpenting adalah bagaimana mencetak guru yang berkualitas.Jika kita bisa mencetak guru yang berkualitas, ini adalah jalan menuju generasi masa depan yang berkualitas.

Hal tersebut sejalan dan selaras dengan harapan dalam uraian kurikulum KKNI. LPTK harus mampu menjadi cermin pendidikan bagi program studi lain sebagai ibu pendidikan karakter serta mau dan mampu menghasilkan pendidik yang humanis, religius, tangguh, kreatif dan penular kebaikan untuk mencapai kemuliaan generasi masa depan. Dari latar belakang tersebut,penelitian memotret proses pelaksanaan pendidikan karakter dan pengembangan kepribadian melalui pendekatan humanis-religius bagi mahasiswa calon guru agama Islam di STAIN Salatiga (saat ini IAIN Salatiga).

Sepanjang penelusuran penulis, ada beberapa penelitian yang memiliki kedekatan sudut pandang dengan kajian ini. Penelitian yang ditulis oleh Muhammad Walid tentang model pendidikan karakter di PTAI (studi tentang pendidikan karakter berbasis ulul albab di UIN Maulana Malik Ibrahim).Dalam penelitiannya, penulis menekankan pendidikan karakter berbasis ulil albab sebagai dasarnya. Hal ini didasari munculnya keprihatinan dan memberikan perhatian banyak untuk pembentukan karakter mahasiswa. Usahanya memberikan alumni memiliki kedalaman spiritual, karakter yang besar, pengetahuan kelengkapan, dan kematangan profesional serta empat konsep yang menjadi acuan dalam grand design pendidikan karakter sebagaimana yang dikembangkan oleh Kemendiknas. Empat konsep tersebut adalah pertumbuhan aspek kognitif, afektif, konatif, dan psikomotorik. Dalam mengembangkan karakter siswa, UIN Maliki Malang berdasarkan pada basis nilai-nilai keberadaan UIN dan visimisi universitas.

Kajian ini dilaksanakan di Jurusan Tarbiyah Program Studi Pendidikan Agama Islam STAIN Salatiga (saat ini IAIN Salatiga) 
dengan menggunakan metode pendekatan deskriptif kualitatif. Penelitian diskriptif kualitatif yaitu penelitian tentang data yang dikumpulkan dan dinyatakan dalam kata-kata dan gambar. Katakata disusun dalam kalimat, misalnya kalimat hasil wawancara antara peneliti dan informan. Dalam pelaksanaanya menggunakan strategi multi metode yaitu wawancara, pengamatan, serta penelaahan dokumen/studidokumenter yang antara satu dengan yang lain saling melengkapi, memperkuat dan menyempurnakan (Sukmadinata, 2008: 108).Teknik analisa data dalam penelitian ini menggunakan Model Analisis Interaktif Miles dan Huberman (1992: 20).

\section{B. Pembahasan}

\section{Pendidikan Humanis-religius dalam ajaran Agama}

Dalam kacamata pendidikan Islam, sebagaimana Baharudin dkk (2007:23) menuturkan bahwa pendidikan humanis adalah proses pendidikan yang memandang manusia sebagai manusia, yaitu makhluk hidup ciptaan Allah dengan fitrahfitrah tertentu untuk dikembangkan secara optimal.Pendekatan humanis dalam pembelajaran merupakan sebuah pendekatan yang memandangbahwa proses belajar seseorang bukan sematamata sekedar menguasi sejumlah ilmu yang sifatnya kognitif semata. Namun, lebih jauh dari itu, bahwa pendidikan dengan pendekatan humanis merupakan sebuah proses yang melibatkan seluruh unsur yang mencakup kognitif, afektif dan psikomotorik.

Teori humanis-religius menjadikonsep dasar cita-cita bangsa Indonesia dalam pengembangan pendidikan. Hal ini dapat diketahui dari rumusan dasar Negara Republik Indonesia yang mengandung pemahamanbahwa praktik pendidikan yang diharapkanoleh para pendiri bangsa Indonesia adalahpendidikan yang bercorak humanis-religius.Konsep ini ditarik dan diabstraksikan daribunyi teks Pancasila, terutama sila pertamadan kedua, yaitu Ketuhanan yang Maha Esa dan Kemanusiaan yang Adil dan Beradab.Pancasila menjadi dasar dari Pendidikan NasionalIndonesia yang berdasarkan pada pandangan humanis religius (Jumarudin, dkk, 2014: 116). 
Dengan teori ini, diharapkan setiap lembaga pendidikan memiliki semangat untuk menyampaikan nilai-nilai karakter dan kepribadian yang bersumber dari masing-masing ajaran agama. Menurut Adhiatera bahwa dalam konsep pendekatan humanisreligius sangat mementingkan nilai-nilai kemanusiaan dalam setiap penghayatan dan pengamalan kehidupan beragama (2008:173). Dengan mengedepankan nilai-nilai ajaran agama akan diperoleh sebuah hasil yang lebih universal terkait dengan nilai-nilai karakter dan kepribadian yang syarat dengan kemanusiaan.

Berbicara tentang nilai-nilai kemanusian tentunya tidak bisa lepas dari karakter dan kepribadian manusia. Khusunya dalam pendidikan karakter, akar kata karakter berasal dari bahasa Yunani yang berarti "to mark" atau menandai dan memfokuskan tata cara mengaplikasikannilai kebaikan dalam bentuk tindakan atau tingkah laku (Saebani, 2013: 30). Dalam proses pendidikan karakter, Lickona (1991: 51) menekankan pentingnya tiga komponen karakter yang baik (components of good character), yaitu moral knowing atau pengetahuan tentang moral, moral feeling atau perasaan tentang moral dan moral action atau perbuatan bermoral. Hal ini sangat diperlukan agar peserta didik mampu memahami, merasakan sekaligus mengerjakan nilai-nilai kebajikan. Proses pelaksanaan pendidikan karakter ini sangat erat kaitanya dengan pendidikan humanisme dan moral. Dengan pelaksanaan pendidikan karakter tentunya pendidik memposisikan peserta didik selayaknya individu manusia yang memiliki kepribadian untuk berubah kearah lebih baik.

Istilah karakter dalam kajian Islam memiliki kesamaan makna dengan akhlak, meskipun beberapa tokoh masih memperdebatkan antara keduanya. Akan tetapi, hal tersebut bukan menjadi persoalan utama dalam kajian ini. Mengenai "akhlak dan karakter", menurut penulis memiliki makna yang sama meskipun akar kata keduanya berbeda. Kata "akhlak" berasal dari bahasa Arab yaitu khuluq, sedangkan kata "karakter" berasal dari bahasa Yunani yaitu kharassein. Kata "akhlak" lebih banyak digunakan oleh lingkungan keagamaan terutama pada lingkungan pendidikan Islam. Sementara itu, kata "karakter" lebih banyak digunakan secara nasional formal, misalnya "karakter bangsa". 
Menurut Ibn Rusn (1998: 99) mengutip pendapatnya imam Al Ghazali dalam Ikhya' Ulum Al-Din kurang lebihnya menjelaskanbahwa akhlak adalah suatu sikap yang telah terpatri kuat dalam jiwa manusia sehingga dengan mudahnya tanpa perlu pemikiran ataupun pertimbangan akan melahirkan berbagai perbuatan. Apabila perbuatan tersebutbaik dan terpuji menurut akal dan syara, maka ia disebut akhlak baik, sebaiknya apabila perbuatan tercela yang keluar darinya, itulah akhlak buruk.

T. Ramli menjelaskan bahwa karakter memiliki esensi dan makna yang sama dengan pendidikan akhlak (Wibowo, 2013:39). Hal senada diungkapkan oleh Fuad Wahab dalam bukunya Hamid (2013:30) bahwa istilah karakter sama dengan istilah akhlak dalam pandangan Islam karena keduanya memiliki tujuan yang sama. Meskipun memiliki kesamaan, akan tetapi prinsipnya berbeda. Dalam karakter tidak ada kepastian apakah kebiasaan itu baik atau buruk. Bisa jadi kebiasaan perilaku di Eropa dinilai baik, belum tentu di Asia bagian timur lainya kebiasaan perilaku itu baik. Sifatnya relatif tergantung manusia dan bahkan kepentingannya. Prinsip religius disini adalah nilai-nilai karakter yang bersumber dari ajaran agama. Karakter yang bersumber dari ajaran agama akan lebih universal.

Khusus dalam ajaran agama Islam, terdapat konsep akhlak. Akan berbeda jauh dengan konsep karakter diatas. Pada nilainilai akhlak, yang didefinisikan cenderung kepada sifat, perangai atau kepribadian. Tidak disebutkannya dalam pengertian itu baik dan buruk, karena akhlak sumber nilainya jelas dan universal yaitu bersifat religius-spiritual dalam arti lain agama (Islam). Bisa disimpulkan bahwa akhlak memiliki cakupan yang jauh lebih luas daripada karakter sehingga mampu menjadi kontrol utama dalam pendidikan karakter.

\section{Konsep Pendidikan Karakter di Perguruan tinggi}

Sebuah perguruan tinggi pencetak pendidik-pendidik bangsa akan bermakna tinggi dan berkarakter manakala semua civitas akademika yang ada bersama-sama membangun nilainilai luhur yang baik. Hal tersebut bisa ditempuh dengan menginternalisasikan nilai-nilai akhlakul karimah untuk 
mengembangkan kepribadian menuju manusia yang diridlai Allah SWT serta berjiwa amar makruf nahi munkar. Hal itu harus selalu melekat dalam pikiran, perkataan, tindakan, kebiasaan sehingga menjadikan ciri khas atau karakter dalam budaya perguruan tinggi Islam. Dalam pendidikan karakter, akhlak memiliki keterkaitan dengan misi humanisasi di segala bidang, khususnya dilingkungan pendidikan.Hal tersebut sejalan dengan pendapatnyaZuchdi (2015: 167), bahwa humanisasi pendidikan perlu segera dijadikan misi setiap lembaga pendidikan di Indonesia supaya nilai-nilai dasar toleransi, inklusifitas, dan kemajemukan menjadi landasan dalam pembentukan akhlak dan moral bangsa.

Dengan nilai-nilai agama yang diberikan dengan baik akan berimplikasi selama menjadi mahasiswa dan tentunya kedepanya menjadi bekal kelak setelah menjadi alumni. Salah satu upaya yang lebih adaptik dalam menciptakan perguruan tinggi Islam yang berkarakter Humanis-Religius adalah dengan mendesain perguruan tinggi Islamdengan pendidikan berbasis akhlak yakni menciptakan insan yang memiliki kedalaman spiritual serta syarat akan nilai-nilai budaya bangsa. Hal ini juga dipertegas oleh Nizar (2001:167) bahwa pendidikan karakter di perguruan tinggi bisa dicapai dengan menciptakan insan yang agamis dan berbudaya. Terkait konsep pelaksanaan pendidikan karakter di perguruan tinggi,menurut Kemendikbud RI tahun 2011 adalah sebagai berikut:

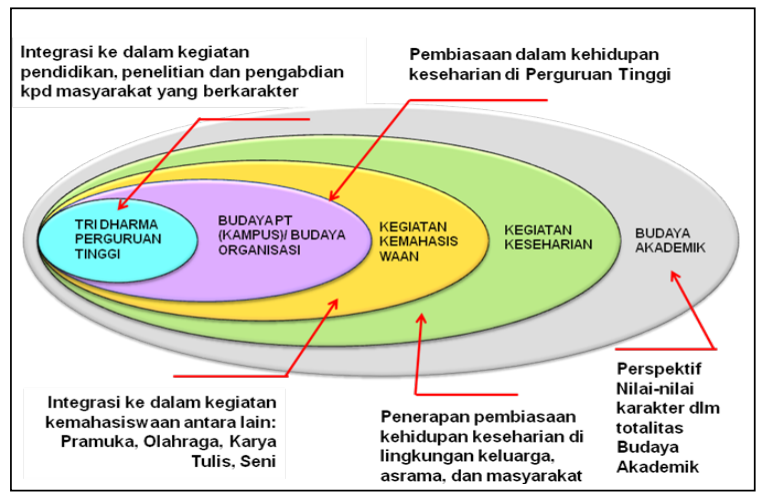

Gambar 2. Pelaksanaan Pendidikan Karakter di Perguruan Tinggi. 
Menurut Zamroni (2011) sebagaimana dikutip oleh Wibowo (2013: 144) menawarkan tujuh strategi pendidikan karakter yang bisa diterapkan di perguruan tinggi, diantaranya:

1. Tujuan, sasaran dan target yang ingin dicapai harus jelas dan konkrit, hal ini tertuang dalam visi, misi baik institusi, jurusan dan prodi yang dijabarkan memalui rencanarencana strategis.

2. Akan lebih efektif apabila dalam pelaksanaanya menjalin sinergi dan kerjasama antara perguruan tinggi dengan orang tua/wali mahasiswa.

3. Memberikan kesepahaman pada semua dosen akan peran penting dan tanggung jawab terhadap keberhasilan pelaksanaan pendidikan karakter.

4. Pentingnya kesadaran dan tanggung jawabdosen akan perlu dan pentingnya "hidden curriculum" sebagai instrument pengembangan kepribadian mahasiswa, dan kesadaran dosen untuk memanfaatkan dan memaksimalkan kurikulum tersembunyi tersebut.

5. Penekanan daya kritis dan kreatif mahasisiwa (critical and creative thinking)dalam proses pembelajaran.

Kultur perguruan tinggi harus didesain dan diberdayakan secara maksimaldalam upaya pengembangan karakter mahasiswa, dari mulai nilai-nilai, keyakinan, norma, semboyan-semboyan (slogan) sampai kondisi fisik kampus sehingga fungsional untuk pengembangan karakter

Pada hakikatnya, salah satu fase pendidikan karakter merupakan proses pembiasaan dalam kehidupan sehari-hari khususnya dalam lingkungan keluarga, kampus dan masyarakat yang dapat dimonitor dan dikontrol oleh dosen, dan orang tua wali mahasiswa.

\section{Desain Pendidikan Karakter di Prodi PAI IAIN Salatiga}

Dalam konteks membangun karakter calon pendidik, penyiapan calon guru profesional yang berkarakter tentunya memiliki korelasi yang tinggi.Sebab setiap calon guru dewasa ini dituntut memiliki kemampuan dalam membina karakter 
peserta didiknya.Oleh karena itu pembinaan karakter mahasiswa calon-calon guru harus menjadi bagian yang tidak terpisahkan dari proses pendidikan profesional guru selama berada dilingkungan kampus.

Kaitannya dengan standar karakter dan kepribadian mahasiswa Program Studi PAI STAIN Salatiga (saat ini IAIN Salatiga) pada umumnya memiliki hubungan erat dengan kompetensi kepribadian guru.Yang menjadi kata kunci karakter mahasiswa sebagaimana ungkapan Rahmat Hariyadi (2014) yang saat itu menjabat sebagai Ketua (saat ini rektor) IAIN Salatiga adalah mahasiswamemiliki kedalam spiritual, keluasan wawasan intelektual, keahlian yang profesional dan berkepribadian sebagai ilmuwan muslim Indonesia. Hal tersebut menjadi sebuah semangat yang dikobarkanagar mahasiswa mampu menjadi seorang intelektual ilmuan muslim yang syarat dengan nilai-nilai ilmu pengetahuan dan budaya ke-Indonesia-an.

Hal senada, khususnya standar karakter bagi calon guru Pendidikan Agama Islam tentunya sangat erat hubungannya dengan kompetensi kepribadian guru (Suwardi: 2014). Dengan demikian, setiap mata kuliah apapun selalu terkait dengan kompetensi kepribadian dan ini menjadi kunci bagi pengembangan karakter calon guru PAI.Menurut penuturan beliau, Proses pendidikan karakter dan kepribadianlebihbersifat hiddencurriculum.

Dari hasil observasi dan dokumentasi yang dilakukan peneliti dilapangan (2014) didapatkan dalam prosesnya,diinterna lisasikanmelalui Tridarma Perguruan Tinggi.Diantaranya adalah:

1. Komitmen bersama seluruh civitas akademika terhadap pembentukan karakter dan kepribadian mahasiswa,

2. Melalui Penciptaan Budaya/interaksi yang bersifat Humanis-Religius dilingkungan kampus (saling senyumsalam-sapa, sikap ramah dan budaya melayani dengan mengedepankan akhlakul karimah),

3. Melalui Unit Kegiatan Mahasiswa (UKM) dengan kegiatan yang terprogram dan terkontrol oleh lembaga dan melalui program ma'had mahasiswa, 
4. Sosialisasi serta pengawalanterhadap tata tertib dan etika mahasiswa No: Dj.I/225/2007 sebagai bentuk pembiasaan kedisiplinan,

5. Melalui pendampingan danmentoring Dosen Pembimbing Akademik(Dosen PA) sebagai bentuk controlingyang bekerjasama dengan Unit TAZKIA (dalam hal ini bagi mahasiswa bimbingan yang tidak mampu tertangani dosen pembimbing akan direkomendasikan dan direver kebagian konseling),

6. Melalui penguatan layanan Bimbingan dan konseling mahasiswa(majelis doa/psikoterapi religius), Pelatihanpelatihanserta ESIQyang dilaksanakan Unit Biro Konsultasi Psikologi TAZKIA,

7. Menjalin kerjasama dan pertemuan denganStakeholder seperti Orangtua, RT/RW dan pemilik kos, pimpinan pesantren dan unsur terkait. (dokumentasi laporan kegiatan)

8. Secara umum terintegrasi pada seluruh mata kuliah yang sifatnya hidden curriculum, akan tetapi secara khusus diterapkan melalui penguatan pendidikan karakter yang terintegrasi pada mata kuliah-mata kuliah yang memiliki core pada Pengembangan Kepribadian (MPK).

Untuk memaksimalkan kajian ini, peneliti membatasi pembahasan pada cakupan mata kuliahpengembangan kepribadiansebagaimana dalam SK Dirjen Dikti No. 43 tahun 2006 tentang rambu-rambu pelaksanaan kelompok mata kuliah pengembangan kepribadian di perguruan tinggi. Adapun visidari mata kuliah tersebut adalah sebagai berikut:

Visi kelompok MPK di perguruan tinggi merupakan sumber nilai dan pedoman dalam pengembangan dan penyelenggaraan program studi guna mengantarkan mahasiswa memantapkan kepribadiannya sebagai manusia Indonesia seutuhnya.

Sesuai dengan Kepmendikan No. 232/U/2000 tentang Pedoman Penyusunan Kurikulum Pendidikan Tinggi dan Hasil Belajar Mahasiswa,mata kuliahdiklasifikasikan menjadi lima rumpun. Mata kuliah tersebut mencakup Landasan kepribadian 
(Mata kuliah Pengembangan Kepribadian: MPK), Penguasaan ilmu dan keterampilan (Mata kuliah Keilmuan dan Keterampilan: MKK), Kemampuan berkarya (Mata kuliah Keahlian Berkarya: $\mathrm{MKB})$, Sikap dan perilaku dalam berkarya menurut tingkat keahlian berdasarkan ilmu dan keterampilan yang dikuasai (Mata kuliah Perilaku Berkarya: MPB), Pemahaman kaidah berkehidupan bermasyarakat sesuai dengan pilihan keahlian dalam berkarya (Mata kuliah Berkehidupan Bersama: MBB).

Menurut Machmud dkk (2015:1), diterbitkannya KepMenDikNas ini menyusul kesepakatan menteri pendidikan yang tergabung dalam United Nations Educational Social and Cultural Organization (UNESCO) Perserikatan Bangsa-Bangsa (PBB) tentang perlunya kurikulum pendidikan yang mengandung unsur-unsur "Learning to know, learning to do, learning to be, dan learning to live together".

Keberadaan dosen sebagai aktor utama tentu mengalami perkembangan dan pertumbuhan.Sifat manusia maupun keberadaannya tidaklah terbatas ataupun statis, manusia dapat berubah ketika situasi maupun keberadaannya berubah karena manusia dapat membangun sebuah mekanisme adaptasi dalam perubahan. Melihat hal tersebut menjadi penting untuk membangun komitmen bersama terhadap pendidikan karakter humanis religius yang nyata-nyata bersifat hiddensehingga visimisi perguruan tinggi mampu diimplementasikan dengan baik serta berimplikasi terhadap pembentukan karakter humanis religius mahasiswa yang nantinya menjadi bekal sebagai makhluk baru, pendidik baru generasi bangsa.

\section{Implementasi Pendidikan Karakter dalam Mata Kuliah Pengembangan Kepribadian (MPK)}

Pendidikan karakter dan kepribadian dalam hal ini bersifat hidden curriculumdalam seluruh mata kuliah. Untuk membatasinya penulis mengambil khusus pada rumpun mata kuliahyang core-nya lebih dominan dan mengerucut pada pembentukan kepribadian yaitu dalam rumpun Mata kuliahPengembangan Kepribadian (MPK): 


\section{a. Nilai-nilai Pendidikan Karakter dalam Mata kuliahMPK}

Beberapa mata kuliah yang masuk dalam rumpun Pengembangan Kepribadian (MPK) sebagaimana dokumentasi dalam buku pedoman akademik diantaranya:

Tabel 1. Rumpun Mata kuliah MPK

\begin{tabular}{ccl}
\hline NO & KEL & \multicolumn{1}{c}{ MATA KULIAH } \\
\hline 1 & MPK & ALQURAN \\
\hline 2 & MPK & PENDIDIKAN KEWARGANEGARAAN \\
\hline 3 & MPK & TAUHID \\
\hline 4 & MPK & SIRAHNABAWIYAH \\
\hline 5 & MPK & AKHLAQTASAWUF I \\
\hline
\end{tabular}

Penjabaran nilai inti(core values)disetiap mata kuliah pengembangan kepribadian sebagai berikut:

1) Mata KuliahAl Qur'an

Nilai-nilai yang terkandung dalam matakuliah $\mathrm{Al}$ Qur'an terbagi menjadi empat hal.Pertama, nilai yang terkait dengan hablun minallah (hubungan seorang hamba kepada Allah), seperti ketaatan, keikhlasan, syukur, sabar, tawakal, mahabbah, dan sebagainya.Kedua, nilai hablun minannas, yaitu nilai-nilai yang harus dimiliki oleh seseorang khususnya terkait hubungannya dengan sesama manusia, seperti rasa empati, rasa kasih-sayang, budaya tolongmenolong, kerjasama, saling mendoakan dan memaafkan, sikap hormat-menghormati, dan sebagainya.

Ketiga, nilai yang berhubungan dengan hablun minannafsi (diri sendiri), seperti: kejujuran, disiplin, amanah, mandiri, istiqamah, keteladanan, kewibawaan, optimis, tawadhu', dan sebagainya. Dan keempat, nilai hablun minal-'alam (hubungan dengan alam sekitar), seperti: keindahan, kepekaan, keseimbangan, kelestarian, kebersihan, kepeduliaan, dan lain sebagainya.

2) Mata KuliahPendidikan Kewarganegaraan

Tujuan mata kuliah ini adalah membentuk mahasiswa agar menjadi ilmuwan muslim yang profesional, 
memiliki rasa kebangsaan dan cinta tanah air, demokratis berkeadaban, menjadi warga negara yang memiliki daya saing, berdisiplin dan berpartisipasi aktif dalam membangun kehidupan yang damai berdasarkan sistem nilai Pancasila(dokumentasi silabus).

Tiga aspek fundamental yang menjadikan ciri mata kuliah ini yaitu pengetahuan kewarganegaraan, keterampilan kewarganegaraan dan sikap kewarganegaraan sebagai berikut:

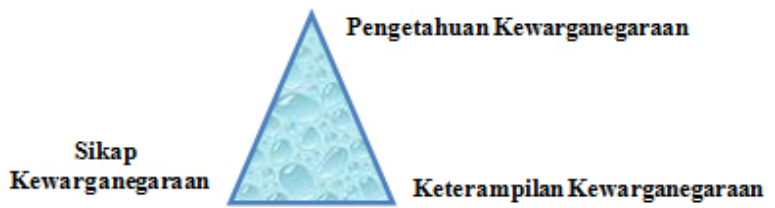

Bagan 3. Tiga Aspek Fundamental Nilai dan Karakteristik PKn

Bangunan tersebut akan selalu diawali dengan pemahaman terhadap konsep atau teori yang kemudian bagaimana konsep tersebut bisa diimplementasikan dalam kehidupan sehari-hari. Kaitannya denganNilai-nilai karakter untuk Mata kuliah PKn meliputi nilai karakter pokok dan nilai karakter utama. Nilai karakter pokok Mata kuliahPKn yaitu: Religiusitas, Kejujuran, Kecerdasan, Ketangguhan, Demokratis, dan Kepedulian. Sedangkan nilai karakter utama Mata kuliahPKn yaitu: Nasionalis, Kepatuhan pada aturan sosial, Menghargai keberagaman dan kemajemukan, Kesadaran akan hak dan kewajiban diri dan orang lain, bertanggung jawab, berpikir logis, kritis, kreatif, dan inovatif, dan Kemandirian.

3) Mata Kuliah Akhlak Tasawuf

Dalam deskripsi mata kuliahakhlak tasawuf mahasiswa diajak untuk memahami dan menganalisis akhlak tasawuf dalam kehidupan modern, tujuan akhlak tasawuf, bagaimana mengelola hati sebagai inti pendidikan akhlak seperti taubat, sabar, zuhud, kekuatan sedekah, khouf wa raja', hubb, fana', dankekuatan sedekah. 
Beberapa nilai dan karakteristik mata kuliah ini adalahpenguatan aspek spiritual lebih ditekankansehingga mampumemahami dan mengenal Allah sebagai dasar pembentukan akhlakdan yang paling utama melalui aspek spiritual inilah yang sebenarnya menjadi basic utama untuk membentuk karakter kuat.Membenahinya bukan pada perilaku, tetapi melalui pengenalan kecintaan Allah SWT kepada makhluknya, dengan hal tersebut manusia akan merasa rikuh, malu kepada Allah SWT, mereka menjadi semakin dekat dan semakin cinta kepada Allah dan efeknya kepada perubahan sikap.

4) Mata Kuliah Sirah Nabawiyah

Bagi para guru, aspek ini menjadi sangat penting. Mempelajari sejarah hidup Nabi saw akan memberikan banyak pelajaran, bimbingan, dan inspirasi tentang cara mengemas Islam agar tidak sekadar kognitif semata melainkan juga efektif menghasilkan perubahan karakter. Apabila mengkaji lebih dalam kehidupan Nabi SAW sangat sarat dengan nilai-nilaikarakter.Kelembutan, kesabaran, sikap arif dan bijaksana.Pribadi nabi yang memiliki sifat sidiq, amanah, fathonah dan tabligserta sejarah kemunculan gelar Al Amin pada diri nabi menjadi standar pribadi ummat yang wajib diteladani dalam hidupseorang calon guru. Hal tersebut selaras dengan misi dimana nabi diutus. Muthahari menjelaskan bahwa misi utama diutusnya Nabi adalah mengajak umat manusia ke arah pengakuan dan pendekatan diri terhadap Tuhan seraya menegakkan keadilan dan kesederajatan dalammasyarakat manusia(Muthahhari,1991:29). Dalam hal ini terlihat nilainilai karakter dan kepribadian yang perlu diteladani dalam usaha menciptakan nuansa humanis-religius.

5) Mata KuliahTauhid

Melalui mata kuliah ini, nilai-nilai utama yang ditekankan adalah karakter keteguhan hati, kemandirian. Disampingi itu, ada sisi rasionalitas agama, karakter yang tampil kuat ini berasal dari rasio agama (wawancara MF: 21 April 2014).Pribadi seorang guru dididik untuk menjadi 
pribadi yang beriman dan berakhlak mulia, memiliki kemantapan dan keteguhan diri, stabil dan dewasa dalam bersikap, kemandirian yang selalu mengedepankan rasionalitas ilahiah yang bersumber dari Allah.

\section{b. PendekatanHumanis Religius dalam Internalisasi Nilai- Nilai Karakter dan Kepribadian}

Dalam proses internalisasi nilai-nilai pendidikan karakter berbasis akhlak dalamMata kuliah Pengembangan Kepribadian akan menjadi standar secara umum karena dalam mata kuliah MPK ini muatan pendidikan lebih kental dengan nilai-nilai softskill. Inilah yang perlu dimengerti dan dipahami oleh semua pihak. Penulis simpulkan dalam prosesnya, beberapa pendekatan yang digunakan baik dalam proses kegiatan pembelajaran ataupun dalam aktifitas akademik lainya diantaranya:

1) Pendekatan Keteladanan

Sikap dan keteladanan yang ditunjukkan seorang dosen dan seluruh pegawaiyang baik akan mampu memberikan nilai positif dan perubahan dalam diri pribadi mahasiswa calon guru. Tindak tanduk, perilaku, ucapan, bahkan gaya mengajar dosen serta interaksi proses pelayanan mahasiswa pun akan sulit dihilangkan dalam ingatan mahasiswa. Begitu pula karakter kepribadian dosen dan pegawai juga selalu terekamdanmembekas dalam memori mahasiswa.

Satu teori yang menarik untuk dikaji bahwa satu teori kognitif sosial yang sangat efektif adalah teorimodeling. Istilah modelling berarti adanya suatu proses peneladanan, peniruan terhadap subyek atau model oleh individu atau kelompok (Tajudin, 2016:39). Hal senada diungkapkan oleh Misdar menurut teori tersebut seorang guru atau siswa adalah orang yang dapatberperan sebagai model, perilaku yang dimunculkan saling berinteraksi denganlingkungan (Misdar,2016:2).

Dosen (civitas akademika) sebagai model (aktor) akan menjadi pusat perhatian yang utama karena dalam 
prinsipnya pembelajaran dalam konteks ini melibatkan pengamatan terhadap model sebagaimana berikut:

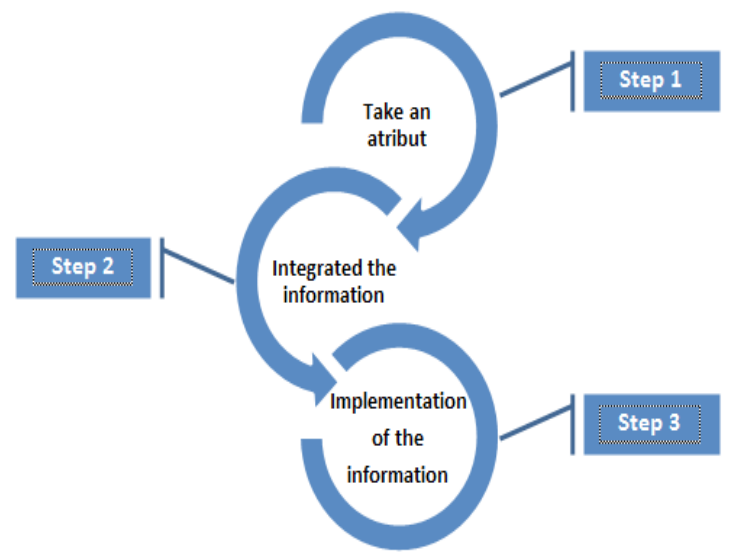

Bagan 4. Tiga Prinsip Strategi Modeling

Manusia cenderung bersifat imitatif. Sesuai dengan Teori kognisi Sosial Albert Bandura yang mengadopsi Perspektif interaksionis dalam menjelaskanFenomenamoral. Pada prosesnya, faktor-faktor personal yang berupa pikiran moral, Reaksi diri Secara afektif, dan perilaku moral, serta faktor-faktor lingkungan berinteraksi secara timbal balik sebagai faktor penentu dalam moralitas (Lestari, 2009:50). Selanjutnya manusia akan memilih model yang dianggap efektif dan mengabaikan model yang penampilan dan reputasinya tidak bagus. Langkah pertama,mahasiswa diajak untuk bisa mengambil atribut yang relevan. Langkah kedua, mahasiswa mengintegrasikan informasi yang didapatkannya melalui pengamatan kedalam sebuah tata aturan yang berlaku. Dan langkah ketiga adalah hasil informasi yang didapatkan diimplementasikan dalam bentuk perilaku yang bersifat psikomotorik.

2) Pendekatan Persuasif

Dengan rasa kedekatan yang syarat nilai-nilai karakter yang dibangun melalui kontrak awal perkuliahandengan pendekatan persuasif akan memberikan hasil yang optimal, nasehat akan mengena manakala dilaksanakan dengan pendekatan hati. Penyampaian nilai berbeda dengan 
penyampaian ilmu yang sifatnya kognitif.Ada segmen dan ranah tersendiri yang tidak bisa diterapkan sebagaimana menyampaikan knowledge, akan semakin efektif manakala dosen juga komiten dengan nilai yang disampaikan tersebut (Sultoni, 2014)

3) Membangun Ikatan Emosional

Posisi dosen sangatlah vital.Dosen ibarat sosok yang dipandang sangat luarbiasa dihadapan mahasiswa. Cara memposisikan dosen dihadapan mahasiswa akan menentukan masuknya nilai inti/ core value dalam diri mahasiswa calon guru. Pendekatan kekeluargaan akan memberikan kenyamanan dan rasa aman bagi mahasiswa, membangun kedekatan ibarat sebuah keluarga, menganggap mahasiswa sebagai anak istimewa, seperti saudara sendiri (dalam koteks pendidikan), tidak membeda-bedakan antar individu akan mampu memberikan perubahan citra diri dan karakter mahasiswa calon guru. Penciptaan lingkungan pembelajaran yang "akrab" antar pendidik dengan subjek didik memungkinkan tumbuhnya rasa aman, rasa kepercayaan, sehingga dengan terbebasnya dari rasa takut untuk tumbuhnya kreativitas. Penciptaan lingkungan pembelajaran yang tidak mengekang mengarah kepada tumbuhnya 'aktualisasi diri' bukan penumpukan pengetahuan (Subiyantoro, 2013: 332).

4) Membangun dan Mengembangkan Pola Pikir Positif

Segala perilaku adalah hasil dari sebuah pemikiran, apabila pikiran yang ada itu baik maka baikpula perbuatannya, akan tetapi apabila sebaliknya pikiran yang muncul itu negatif tentu akan berakibat negatif pula perilaku. Hermawan (2011: 17-18) menegaskan think becomes thing, you are what you are thinking. Kita adalah apa yang kita pikirkan. Jika kita berpikir baik terhadap diri pribadi kita maka baik pula citra diri kita. Dalam hal ini tentunya tidak sekedar hanya proses berpikir, tetapi diiringi dengan menyelaraskan antara pikiran dengan tindakan. 
Sebuah bagan yang akan memperjelas konsep perubahan mindsetyang berdasarkan nilai inti ajaran agama sebagaimana dibawah ini:

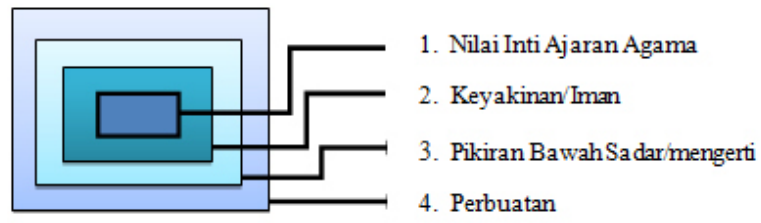

Bagan 5. Komponen Pola Pikir

Melalui pendidikan mindsetyang benar bagi mahasiswa calon guru, Indonesia akan memiliki penguat yang nantinya juga akan kembali ikut menguatkan mindset generasi-generasi muda lainya. Mindset erat kaitannya dengan pikiran/otak manusia. Dengan memahami dan menata mindset (cara berpikir) yang benar, mahasiswa calon guru kedepanya akan mampu mengantarkan masyarakat dan bangsa Indonesia menjadi bangsa yang cerdas, mandiri, sejahtera, dan berbudi luhur, berkarakter dan berkepribadian baik. Pendidikan mindset bukanlah proses mendoktrin yang sekedar menyamaikan dogmadogma.Pendidikan mindset menjelaskan tentang cara kerja otak dan pikiran ketika seseorang melihat dan mendengar informasi salah atau benar. Karakter tersebut dibangun lewat pikiran, kedua dengan pemberian contoh yang sederhana dan konsisten.Untuk menuju perubahan besar dilakukan dengan mengubah carapandang mahasiswa dan mengajak mereka untuk berpikir positif terhadap diri mereka sendiri. Nilai-nilai karakter berbasis agama ditanamkan melalui pikiran bawah sadar karena segala perilaku adalah hasil dari buah pikir.

5) Pendekatan Pembiasaan

Dalam menanamkan nilai-nilai karakter dan kepribadian bukanlah sekedar proses menghafal materi soal ujian, dan teknik-teknik menjawabnya. Karakter atau Akhlak memerlukan sebuah pembiasaan. Pembiasaan untuk berbuat baik, pembiasaan untuk berlaku jujur, ksatria, malu berbuat curang, malu bersikap malas, malu membiarkan 
lingkungannya kotor, hal-hal yang bersifat ritual seperti sholat berjamaah, praktik etika sosial, perlakuan saling menghormati, saling kasih mengasihi antar sesama, saling membantu, menulis, membaca, dan lain-lain.

Salah satu strategi yang dirasa paling efektif adalah membangun sebuah pembiasaan didalam budaya kampus, baik itu budaya didalam perkuliahan dengan berpikir kritis dan inovatif maupun budaya keseharian dilingkungan kampus sepertihanya di unit-unit kegiatan kemahasiswaanatau ma'had, interaksi keseharian, pembiasaan pembacaan doa mulai dan selesai perkuliahan, diskusi yang terkoordinir dengan baik dan sopan serta beberapa pembiasaan lain seperti pembiasaan shalat berjamaah dzuhur di masjid.Karakter tidak terbentuk secara instan, tetapi harus dilatih secara serius dan proporsional agar mencapai bentuk dan kekuatan yang ideal.

6) Pembelajaran Bermakna

Dalam hal ini dosen sebagai the living model bagi mahasiswa khususnya dalam mempelajari sejarah kehidupan Nabi SAW.Dalam prosesnya, fase pertama adalah metode pembentukan dasar dan prinsip bagaimana kita sebagai ummat mengenal Nabi SAW. Setiap peristiwa penting yang terjadi dalam perjalanan hidup Nabi saw harus diingat dengan baik kronoligisya dengan berurutan. Pada tahap ini, metode membaca dan bercerita menjadi prioritas utama dalam perkuliahan.Melihat karakteristik materi ajar siroh nabawiyah, tentunya membaca cepat dan membaca cerdas menjadi ujung tombak, disini metode story telling bisa diterapkan. Pada prosesnya seorang pengajar perlu menggunakan mix-metode, dengan metode yang bervariasi akan semakin meningkatkan antusias peserta didik dalam kegiatan pembelajaran. Metode ini memiliki pengaruh yang sangat menakjubkan untuk dapat menarik perhatian pendengar dan membuat seseorang bisa mengingat kejadian dalam sebuah kisah dengan cepat.

Tahap kedua adalah dari hasil membaca cepat dan membaca cerdas diatas, siswa diajak untuk menganalisis dan 
membangun pemahaman secara mendalam setiap fase-fase peristiwa kehidupan Nabi.Kajian sejarah kehidupan Nabi SAW terfokus pada satu referensi utama yang membahas fase-fase kehidupan Nabi secara kronologis-historis dengan informasi yang cukup lengkap. Dosen memvariasi kegiatan dengan menggunakan metode small group discussion. Hasil bacaan tersebut didiskusikan dalam kelompok-kelompok kecil secara mendalam yang kemudian antar tiap kelompok memaparkan serta menceritakan nilai-nilai kandungan dalam tiap-tiap peristiwa yang terjadi.

Pada tahap ketiga mahasiswamuslimdiharapkan tidak hanya mengetahui peristiwa sejarah kehidupan Nabi SAW, tetapi juga melakukan analisisakhir mendalam terhadap peristiwa yang terjadi dalam kehidupan nabi dan menemukan nilai-nilai kehidupan yang relevan dengan kehidupan sekarang. Pada fase inilah mempelajari sirah nabawiyah efektif mewariskan nilai-nilai karakter untuk diteladani. Dalam hal ini proses pendidikan Islam dituntutmampumembentuk individu muslim syaratnilainilai kearifan. Disinilah letak pembentukan caracter buildinghumanis yang sesungguhnya.

7) Penguatan Aqidah

Aqidah atau keimanan merupakan bagian terpenting dalam ajaran Islam.Apabila dianalogokan, ajaran Islam diibratkan jasad dan iman adalah ruhnya.Ia adalah jantung yang memompa darah kehidupan keseluruh bagian tubuh. Pada akhirnya, dalam setiap perjalanan hidup manusia iman-lah yang akan mengontrol dan sekaligus mengarahkan setiap perbuatan. Aqidah atau keimanan adalah ruh dalam ajaran Islam karena seseorang akan dinilai derajad nya disisi Tuhanya atas dasar keimananya serta ketaqwaanya.Makna keimanan atau tauhid sebagai inti ajaran Islammemiliki dampak sosial yang luar biasa, dalam arti bahwa tidak ada satu pun orang atau tatanan yang dijadikan sebagai rujukan atau tempat bergantung seseorang kecuali Tuhan sendiri. Dengan prinsip ini, semua aktifitas kehidupan 
diorientasikanpada pengabdian pada Tuhan, bukan untuk kepentingan materialis-hedonis duniawi (Muqowim, 8).

Di tengah gelombang modernismdan arus globasisasi, keimanan ini bukan hanya akan menjadi pemandu arah, melainkan ia juga akan menjadi telaga penyejuk di tengah hingar-bingar dan hiruk-pikuknya dunia modern yang penuh dengan problematika.Mulai dari maraknya kasus dehumanisme, kekerasan, maraknya kasus bulliying, ujaran kebencian, tawuran dan lain sebagainya. Mengenalkan mahasiswa dengan Allah, mendekatkannya kepada Allah, menguatkan rasa cintanyakepada Allah, menjadikan Allah satu-satunya pegangan hidup, adapun yang lainya nggandul (red. Jawa)(Wawancara Sultoni, 2014). Inilah nanti yang akan membentuk kepribadian seorang guru sejati, guru yang sudah kenal Allah.Inilah yang akan membawa murid menjadi murid yang berkarakter kuat dan berkepribadian.

8) Integrasi Nilai-Nilai Ajaran Islam

Sangat erat kaitanya dengan point ke-tujuh diatas, bahwa dalam proses internalisasi nilai-nilai karakterdan kepribadian harus terhubung pada tataran ilahiyah. Disini bisa dibahasakan metode integrasi nilai-nilai ajaran Islam atau juga bisa disebut strategi reflektif.Apabila tidak ada keterkaitan antara dimensi ilahiyah (religius-spiritulis), karakter tersebut hanya sebatas pada tataran emosional semata, sangat rapuh dan mudah mengalami perubahan. Melalui peran berbagai elemen salah satunya melalui organisasi kemahasiswaan yang fokus dalam pembinaan keagamaan serta melalui peran ma'had mahasiswa (wawancara RH: 22 Maret 2014).

Dalam ajaranIslam antara dimensi Illahiyah dengan dimensi kemanusiaantidak dapat dipisahkan.Aspek spiritual (illahiyah) inilah yang sebenarnya menjadi basic untuk membentuk sebuah karakter yang kuat. Membenahinya bukan pada perilaku, tetapi melalui pengenalan kecintaan Allah pada manusia.Manusia akan merasa rikuh, malu kepada Allah sehinggamereka akan menjadi semakin mendekat dan cinta kepada Allah dan efeknya adalah perubahan sikap. 
Dalam prosesnya, mahasiswa diajak untuk menggali sebuah peristiwa kehidupan, dosen mengkaitkan dengan masalah masalah prinsip yang terjadi dalam kehidupan yang kemudian ditarik ke ranah Illahiyah, mengenal kuasa-Nya, cinta-Nya.Dengan proses tersebut akan banyak muncul amalan-amalan yang bersifat syari'ah yang secara tidak langsung membentuk karakternya.

Sistem ajaran Islam dikelompokkan menjadi tiga bagian, yaitu bagian aqidah (keyakinan), bagian syariah (aturan-aturan hukum tentang ibadah dan muamalah), danbagian akhlak (karakter Islami). Ketiga bagian ini tidak bisa dipisahkan, tetapi harus menjadi satu kesatuan yang utuh yang saling mempengaruhi. Aqidah sebagai pondasi yang menjadi tumpuan Syariah dan Akhlak. Sementara itu, syariah merupakan bentuk bangunan yang hanya bisa terwujud bila dilandasi oleh aqidah yang benar dan akan mengarah pada pencapaian akhlak yang seutuhnya. Dari adanya aqidah dan syariah yang kuat yang kemudian ditarik kepada bukti rahman-rahimnya Allah, kasih sayangnya Allah serta penguatan konsep ihsan bahwa apapun yang kita lakukan dimuka bumi ini Allah senantiasa menyaksikan. Konsep diatas bisa digambarkan sebagai berikut:

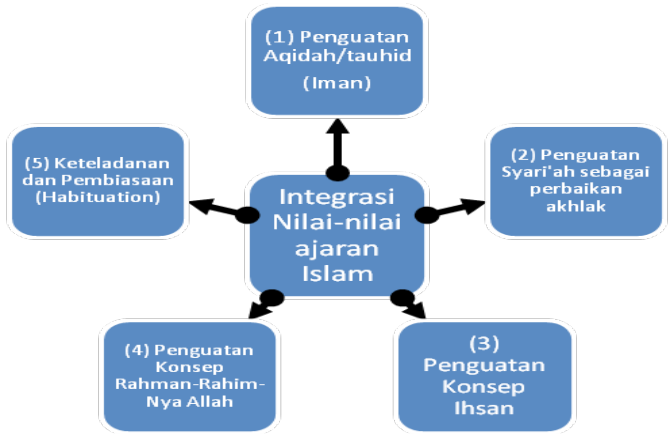

Bagan 6 : Konsep Integrasi Nilai-Nilai Ajaran Islam

Dengan demikian, akhlak (karakter Islami) sebenarnya merupakan hasil atau akibat terwujudnya bangunan syariah yang benar yang dilandasi oleh fondasi aqidah yang kokoh. Tanpa aqidah dan syariah, mustahil akan terwujud akhlak (karakter Islami) yang sebenarnya. 
Melalui integrasi nilai nilai agama ini diharapkan dapat menguatkan dan menjadi pendorong perwujudan nilai-nilai kemanusiaan dalam kehidupan bermasyarakat.

\section{Simpulan}

Dari hasil olah temuan dan konfirmasi peneliti, disimpulkan beberapa hal yang menjadi poin utamapendidikan karakter dan kepribadian melalui pendekatan humanis-religius di LPTK lebih bercorakhidden curriculum. Pada prosesnya dilaksanakan melalui Tridarma Perguruan Tinggi sebagaimana penjelasan pada bagian awal, kaitannya terhadap penguatan pendidikan karakter dan kepribadianyang terintegrasi dalam Mata kuliah pengembangan kepribadian dalam praktiknya sudah efektif, setiap mata kuliah MPK syarat akan nilai-nilai karakter sesuai dengan karakteristik dan tujuan masing-masing mata kuliah, hanya saja diperlukan kerja kolektif kaitannya dengan proses implementasinya.

Pada proses pelaksanaan pendidikan karakter dan kepribadiandigambarkan dalam visi dan misi, disosialisasikan dalam tataran kerja lembaga dan stakeholder, selanjutnya diintegrasikan dalam setiap disiplin ilmu. Dalam menerapkan tata nilai disertai komitmen bersama, dijalankan secara maksimal dengan penuh kesadaran dan tanggung jawab mulai dari kegiatan kerjasama, program team teachingdan diskusi dosen mata kuliahserta nilai-nilai karakteryang dirumuskan secara eksplisit dalam deskripsi mata kuliah, silabi dan SAPsesuai dengan tujuan yang hendak dicapai.

Hal berbeda dalam prosesnya adalah penekanan dalam aspek yang bersifat humanis-religius. Meskipun semua aspek Tridarma Perguruan Tinggi telah dijalankan, tetapi jika tidak didasari dan dilandasi dengan pendekatan humanisme dan religiustentunya akan menghasilkan sebuah karakter yang berbeda. Nilai-nilai agama yang telah diterjemahkan dalam akhlak menjadi pondasi utama karakter dan kepribadian yang selanjutnya nilai-nilai kebaikan tersebut perlu disampaikan dengan cara yang humanis. 


\section{DAFTAR PUSTAKA}

Adhiatera, T. 2008, Perjalanan Spiritual Seorang Kristen Sekuler. Jakarta: BPK Gunung Mulia.

Al Ghazali, Imam, Ikhya' al Ulumuddin, Juz I, Mashadul Husaini.

Baharuddin, dan Moh. Makin, 2007, Pendidikan Humanistik, Yogyakarta: Ar-Ruzz Media.

Chatib, Munif, 2012, Gurunya Manusia, Bandung: Kaifa.

Durkheim, Emile, 1961, Pendidikan Moral: Suatu Studi Teori Dan

Aplikasi Sosiologi Pendidikan, Terjemah : Moral Education, The Free Press of Glencoe, Jakarta: Penerbit Erlangga.

Hamied, Hamdani dkk, 2013, Pendidikan Karakter Perspektif Islam, Bandung: Pustaka Setia.

Hermawan, Didik, 2011, Yes Aku Bisa, Rahasia Membentuk Mental Pemenang Dengan Tehnik Spiritual Hypnoparenting, Solo: Era Adi Citra Intermedia.

Huberman, Miles, 1992, Analisis Data Kualitatif, Jakarta: Universitas Indonesia Press.

Ibn Rusn, Abidin, 1998, Pemikiran AL Ghazali tentang Pendidikan, Yogyakarta: Pustaka Pelajar.

Jumarudin, Abdul Gafur, Siti Partini Suardiman, Pengembangan model pembelajaran humanis-Religius dalam pendidikan karakter di sekolah dasar, Jurnal Pembangunan Pendidikan: Fondasi dan Aplikasi, Volume 2, Nomor 2, 2014.

Kamal, Sulton,PendidikanKarakterPendidikanAkhlak, dalam http: / / hariansinggalang.co.id/pendidikan-karakterpendidikan-akhlak/ diunduh 21 Maret 2014

Kementerian Pendidikan Nasional Direktorat Jenderal Pendidikan Tinggi tahun 2011 tentang Pelaksanaan Pendidikan Karakter di Perguruan Tinggi.

Latief, Hilman dkk(edt), 2015, Islam dan Urusan Kemanusiaan; Konflik, Perdamaian dan Filantropi, ICRC-Jakarta: PT Serambi Ilmu Semesta. 
Lestari. Sri, Pembentukan Karakter pada Anak: Model Mekanisme Sanksi Diri dari Albert Bandura Sebagai Regulasi PerilakuMoral. Buletin Psikologi, Fakultas Psikologi Universitas Gadjah Mada .Volume 17, No. 1, 2009: 48 - 56 Lickona, Thomas, 1991, Educating for Character: How Our School Can Teach Respect and Responsibility, New York: Bantam Books.

Machmud, Ilham \& Frans A.Rumate, 2015, Etika dan Perilaku, Jurusan Farmasi - FMIPA Universitas Hasanuddin. Diakses dari http://www.unhas.ac.id/hasbi/LKPP/HasbiKBK-SOFTSKILL-UNISTAFF-SCL/P3AI-Unhas / ETIKA\%20DAN\%20PERILAKU.doc

Misdar, Muh.Keteladanan Guru Dalam Pembelajaran, JurnalAtTa'lim, Vol. 15, No. 1, Januari 2016

Muqowim, Pendidikan Islam dalam Perspektif Critical Pedagogy. Diakses dari http://digilib.uin-suka.ac.id/8467/1/ MUQOWIM\%20PENDIDIKAN \%20ISLAM \%20 DALAM\%20PERSPEKTIF \%20CRITICAL\%20 PEDAGOGY.pdf

Muslich, Mansur, 2011, Pendidikan Karakter, Menjawab Tantangan Krisis Multidimesional, Jakarta: PT Bumi Aksara.

Muthahhari. Murtadha, 1991. Falsafah Kenabian. Jakarta: Pustaka Hidayah

Nizar, Samsul, 2001, Pengantar Dasar-Dasar Pemikiran Pendidikan Islam, Jakarta: Gaya Media Pratama.

Oktaviana, Zahrina, 2014, Tolak Kekerasan pada Dunia Pendidikan, melalui diakses dari http://edukasi.kompasiana. com/2014/05/03/-653441.html,pada 19 Mei 2014

SK DIKTI No: 43/DIKTI/Kep/2006 tentang Rambu-Rambu Pelaksanaan Kelompok Mata kuliah Pengembangan Kepribadian di Perguruan Tinggi.

Sri Rahayu, Ani, Budaya Perguruan Tinggi Yang Berkarakter, diakses dari http://www.koranpendidikan.com/view/1653/ budaya- perguruan- tinggi-yang- berkarakter. html pada 29 April 2014 
Sriyanti, Lilik, 2012, Model Pembinaan Karakter Mahasiswa Stain Salatiga, Salatiga: Pusat Penelitian dan Pengabdian Masyarakat (P3M).

Subiyantoro, Pengembangan Model Pendidikan Nilai HumanisReligius Berbasis kultur Madrasah, Cakrawala Pendidikan, November 2013, Th. XXXII, No. 3

Sukmadinata, 2008, Nana Syaodih, Metode Penelitian Pendidikan. Bandung: PT Remaja Rosda Karya.

Syamsudin, Din, 2012, Masalah Bangsa Indonesia Berpangkal

Pada Krisis Moral, diakses dariwww.tribunnews.com/ nasional/2012/08/19, pada 23 Mei 2014

Tajudin, Yuliyatun. Islam Dan Masyarakat Modern Dalam Sistem Modeling Masyarakat Jawa. Jurnal Community development. Volume 1, No. 1, Juni 2016

Wibowo, Agus, 2013, Pendidikan Karakter di Perguruan Tinggi. Membangun Karakter Ideal Mahasiswa di Perguruan Tinggi, Yogyakarta: Pustaka Pelajar.

Zubaidi, 2011, Desain Pendidikan Karakter, Jakarta: Prenada Media Group. 